\title{
Sources and Levels Effect of Sodium Selenite and Selenium Enriched Yeaston Carcass Characteristics in Broiler Chicken
}

\author{
Roshan Kumar Sahu*, M. K. Gendley, Meenu Dubey, G. K. Dutta, Ramchandra \\ Ramteke, Raina Doneria, SonaliPrusty and Kiran Kumari
}

College of Veterinary Science \& A.H, Anjora Durg, C.G.K.V., C.G, India

*Corresponding author

\section{A B S T R A C T}

Keywords

Broiler, Sodium selenite, Selenium enriched yeast, Carcass

characteristics,

Meat quality, Water

Holding

Capacity(WHC),

Extract Reserve

Volume (ERV),

Thiobarbituric Acid

(TBA).

Article Info

Accepted:

15 September 2020

Available Online:

10 October 2020
A total of 180-day-old broiler chickens (Ross AP strain) were allocated to 4 dietary treatments to evaluate the effects of two sources and levels of selenium and their interaction on carcass characteristics and meat quality in broiler chicken reared under deep litter system in a well-ventilated house with standard management practices. The experiment consisted of $2 \times 2$ factorial arrangement with 2 sources of dietary Se [Sodium selenite (SS), and Selenium enriched yeast (SY)] and 2 levels of supplemental Se (low: $0.15 \mathrm{mg} / \mathrm{kg}$, and high: $0.50 \mathrm{mg} / \mathrm{kg}$ ). Each treatment had 3 replicates of 15 broiler chickens per replicate. Two birds from each replicate were sacrificed to study carcass characteristics (dressed, liver, heart, intestine, breast, thigh, wing, neck, back and giblet weight \%) and meat quality (WHC, ERV and TBA value) at $35^{\text {th }}$ day of age. Findings suggested that adding of $0.5 \mathrm{ppm}$ of selenium enriched yeast supplementation showed significant $(\mathrm{p}<0.01)$ difference in WHC percentage, breast weight percentage and dressing percentage, however, TBA value supplemented with sodium selenite was significantly $(\mathrm{p}<0.01)$ higher than selenium enriched yeast supplementation.

\section{Introduction}

Broiler production has been the fastest growing sub sector of Indian agriculture with a quantum jump with respect to broiler population as well as productivity.Feed represents the major cost of poultry production, constituting up to 70 percent of the total feed cost, about $95 \%$ is used to meet energy and protein requirements, about 3-4 \% for major mineral, trace mineral and vitamin requirements, and $1-2 \%$ for various feed additives (DAHDF., 2017). The growth in the broiler segment is expected to remain strong due to consumer preference for poultry, increasing income levels, and changing food habits. With the increasing demand and need of poultry sector in India, poultry must be 
provided with adequate nutrition and balanced diet. It is a well-established fact that tables of feeding standards as well as breed manuals state the nutrient requirements of the birds at different stages of production only under normal condition and do not pay attention to the extra nutrient required in disease and/or stress conditions (Alian et al., 2020).

The birds that are being reared in open-sided poultry houses may lead to stress due to constant dynamic variations in temperature and humidity in the environment, which causes adverse effects on performance (Niu et al., 2009), and meat quality (Thompson and Scott, 1969). High environmental temperature in the tropical countries causes heavy financial losses to poultry due to reduced feed intake and decreasing feed conversion efficiency. Meat quality and stability are affected mainly by the lipid peroxidation which is related to the production of free radicals and reactive oxygen species (ROS), which are produced as a part of the normal cell metabolism (Tappel and Tappel, 2004). Excessive reactive free radicals will reduce meat sensory traits and nutritional values (Mohamed et al., 2020). Furthermore, in a several physiological and pathological states, excess amounts of ROS are generated (Fridovich, 1978), which damages the cell phospholipid membranes and other macromolecules (Wiseman and Halliwell, 1996).

Lipid oxidation is an important determinant of shelf life of meat and meat products. Postslaughter biochemical changes involved in the conversion of muscle to meat are accompanied by a loss of cellular antioxidant defences and an increased propensity of meat lipids to undergo oxidation (Morrissey et al., 1994). This contributes to undesirable changes in a number of quality parameters, including loss of water-holding capacity, texture and flavour. Microbial growth leads to the precipitation of public health hazards which, in turn, contribute to the deterioration in meat products during storage (FernandezLopez et al., 2005). Due to the above reasons, consumers are more interested in the beneficial health promoting effects of functional foods enriched with natural ingredients. This has led to the opportunities for marketing meat products with added nutritional value and quality (Grashorn, 2007). Utilization of appropriate antioxidants will help the biological system by scavenging reactive oxygen, which intern reduces lipid peroxidation (LP) and increase activity of antioxidant defense system (Nunes et al., 2005). In living organisms, antioxidant processes protect the body cells from the harmful effects of free radicals (Rotruck et al., 1973).

Selenium (Se) is an essential trace mineral for poultry nutrition and great information has been collected during the previous 20 years indicating that dietary form of Se is a major determinant of its efficiency. It is the component of at least 25 selenoproteins that participate in redox balance maintenance and antioxidant defences (Surai and Fisinin, 2014). The importance of $\mathrm{Se}$ is principally associated with its role as an essential part of the glutathione peroxidases (GSH-Px) which provide a defense against oxidative stress by catalyzing the reduction of hydrogen peroxide and lipid peroxides to less harmful hydroxides (Baltic et al., 2015).

Selenium deficiency results in a number of disorders and injuries in poultry, such as skeletal myodegeneration, exudative diathesis (ED), muscular haemorrhages, atrophy of pancreas, decreased production of eggs, liver injury, reduced hatchability, and inhibited growth of bursa and thymus (Gao et al., 2012). Animal and poultry feed require Se supplementation to ensure sound health, efficient performance and good meat quality. 
An insufficient Se supply has negative effects on the performance of chickens (Bakhshalinejad et al., 2018). The supplementation of $\mathrm{Se}$ is necessary for maintaining the high performance of broiler chickens (Perić et al., 2009).

The bioavailability of selenium is linked to its physical form. Currently, sodium selenite is the most commonly used selenium source in animal feeds; however, it has some disadvantages of lower availability, as well as potential toxicity at higher concentration (Suchy et al., 2014). On the other hand, organic forms like selenium-enriched yeast and selenomethionine are utilized in many countries as a safer and better source of Se in animal feed (Mohamed et al., 2020). The main and foremost advantage is its bioavailability. Organic selenium can be utilised to synthesize selenoproteins and excess selenium can be stored in a protein pool for different applications. But in case of inorganic forms are utilised for synthesis of selenoproteins and the excess selenium is excreted. Secondly organic selenium improves the antioxidant properties by increasing the GSH-Px and tissue selenium concentration in comparison to inorganic sources (Payne and Southern., 2005). Thirdly organic selenium fails to undergo prooxidation unlike inorganic selenium as it already exists in an organic form (Mohanty et al., 2018). The basic advantage in chelating of mineral is improved bioavailability due to firm binding of metallicions with organic molecule like amino acid e.g. Selenised Yeast. Organic selenium from yeast having improved bioavailability due to better solubilisation, greater stability in the lumen and provides antioxidant protection at greater level than inorganic selenium (Mahmoud and Edens., 2003).

There are various opinions of scientist about various level of inclusion of $\mathrm{Se}$ and different source of Se in the diet of poultry for better performance on growth and egg production. Food and Drug Administration, USA, (2000) has approved the use of selenium as sodium selenate or selenite in poultry feed at levels of $0.3 \mathrm{mg} / \mathrm{kg}$ of diet, while the NRC (1994) and ICAR (2013) have recommended a level of $0.15 \mathrm{mg}$ of $\mathrm{Se} / \mathrm{kg}$ feed in broilers. The inclusion level of $0.5 \mathrm{mg} / \mathrm{kg}$ of selenium appeared to have better overall performance when fed to broiler chicken (EC. 2014 and Okunlola et al., 2015). Considering these facts, the aim of the present study was planned to evaluate the carcass characteristics and meat quality parameter in broiler chicken fed on two sources and levels of selenium.

\section{Materials and Methods}

\section{Housing and management}

The experiment was conducted in the Department of Animal Nutrition, College of Veterinary Science and Animal Husbandry, Anjora, Durg (C.G.). 5 weeks feeding trial was carried out on 180 day old Ross AP Strain broiler chicks housed under the deep litter system, in a well-ventilated room with standard management practices. The chicks were weighed individually and randomly allocated to 4 treatment groups with 3 replicates of 15 chicks each.

\section{Treatment and additives}

Ingredient and nutrients composition of diets for chicks at 0 to 35 days old were based on the Indian Council of Agriculture Research (ICAR, 2013) recommendations. Four isonitrogenous and isocaloric diets were formulated. The different dietary treatments were includes: Diet 1 (T1) \& 2 (T2) contained basal diet with inorganic source of Selenium $\left(\mathrm{Na}_{2} \mathrm{SeO}_{3}\right)$ @ 0.15 ppm \& 0.5 ppm, respectively. Similarly diet 3 (T3) \& 4 (T4) contained basal diet with organic source of 
Selenium (Selenium enriched yeast) $@ 0.15 \mathrm{ppm} \& \quad 0.5 \mathrm{ppm}$, respectively. The ingredient compositions of experimental diets for pre-starter, starter \& finisher phase are presented in Table 1.

\section{Carcass Characteristics}

Two birds from each replicate were slaughtered on 35th days of experiment. Prior to slaughter, birds were offered no feed for 12 hours and then weighed individually (preslaughter weight).

The selected birds were slaughtered by halal method and then after head and feather were removed. Both the legs were knuckled from hock joint. Abdomen was opened for evisceration and carefully all the viscera including organs of alimentary tract, air sacs, giblets (gizzard, liver and heart) and spleen were separated from carcass. The organs like gizzard, liver, heart, spleen and different cuts of carcass like thigh, wing, back and neck and breast were weighed using sensitive balance. Lastly eviscerated carcass along with giblets and spleen were weighed for calculating dressing percentage.

\section{Meat Quality Parameter}

The meat samples were analysed for various meat quality parameters on $0^{\text {th }}$ day (fresh). The various meat quality parameters viz Extract release volume was determined by Pearson, 1968 and Water Holding Capacity (WHC) was estimated by Harris and Shorthose., 1988. The thio barbituric acid number was determined by Strange et al., 1977with slight modification.

\section{Statistical Analysis}

For interpretation of the results, the data of two levels of doses and two sources of Selenium were subjected for analysis of variance following $2 \times 2$ factorial schemes as per the Snedecor and Cochran 1994. The significance of difference due to two levels of doses and two sources of selenium supplementation and interaction effect of levels and sources were analysed by Duncan's Test (1955).

\section{Results and Discussion}

The effect of two levels and sources of sodium selenite and selenium enriched yeast on carcass characteristics (dressed wt., liver, heart, intestine, breast, thigh, wing, back and neck and giblet) and meat quality (Water Holding Capacity (WHC), Extract Reserve Volume (ERV), Thiobarbituric Acid (TBA) value parameters is presented in Table 2 and 3.

\section{Carcass Characteristics}

Dressing wt. (\%) did not vary significantly due to supplementation of two levels of sodium selenite, however, two level of selenium enriched yeast showed significant $(p<0.01)$ difference. The dressed weight with $0.5 \mathrm{ppm}$ Se group was highly significant $(\mathrm{p}<0.01)$ than 0.15 group.

No significant ( $p>0.05)$ effect on liver, heart, intestine, thigh, wing, back and neck and giblet wt. percentage due to two levels of selenium supplementation was recorded, however, breast wt. percentage and dressing percentage differed significantly $(\mathrm{p}<0.05)$ due to $0.5 \mathrm{ppm}$ of selenium enriched yeast supplementation.

The finding was corroborated with the finding of earlier researcher (Payne and southern., 2005; Deniz et al., 2005., Savcikova et al., 2006; Mikulski et al., 2009 Da Silva et al., 2010; Yang et al., 2012; Rao et al., 2013; Rajashree et al., 2014; Oliveira et al., 2014; Boostani et al., 2015; Prasad, M. V., 2019) 
reported no significant $(\mathrm{p}>0.05)$ affect due to supplementation of different level of selenium or different source of selenium, however, most of the researcher (Naylor et al., 2000; Choct et al., 2004; Heindl et al., 2010; Baltic et al., 2015; Markovik et al., 2018) reported higher breast meat and dressing weight percentage due to supplementation of higher level of organic selenium in poultry, who advocated higher breast weight percentage might be due to higher amount of organic selenium deposition in the breast weight. Similarly higher dressing percentage might be due to higher growth performance in organic selenium supplemented group.

\section{Meat Quality Parameter}

The water holding capacity (WHC) and Thiobarbituric Acid (TBA) value due to supplementation of two levels of sodium selenite and selenium enriched yeast did not differ significantly. Similarly ERV (ml) due to two level of sodium selenite did not vary significantly $(\mathrm{p}>0.05)$, however, ERV (ml) supplemented with two level of selenium enriched yeast differed significantly $(\mathrm{p}<0.05)$ in 0.5 ppm Se supplemented group. The ERV (ml) due to overall level and source effect did not show significant ( $p>0.05)$ difference, however, interaction effect differed significantly $(\mathrm{p}<0.05)$.

Table.1 Ingredients composition of experimental diets for pre-starter, starter $\&$ finisher feed

\begin{tabular}{|l|c|c|c|}
\hline Ingredient (\%) & Pre-starter feed & Starter feed & Finisher feed \\
\hline Maize & 55.72 & 52.72 & 61.66 \\
\hline Soy DOC & 37.95 & 37.92 & 30.80 \\
\hline Soy. Oil & 2.86 & 5.24 & 3.70 \\
\hline DCP & 1.28 & 2.17 & 2.00 \\
\hline LSP & 1.08 & 0.78 & 0.70 \\
\hline Lysine & 0.42 & 0.01 & 0.04 \\
\hline Methionine & 0.14 & 0.23 & 0.14 \\
\hline Choline -60\% & 0.08 & 0.10 & 0.12 \\
\hline Salt & 0.35 & 0.39 & 0.29 \\
\hline Premix & 0.42 & 0.42 & 0.50 \\
\hline Soda- bi-carb & 0.09 & 0.32 & 0.42 \\
\hline & & Calculated value & 3100 \\
\hline ME( kcal/kg) & 3000 & 3100 & 19.50 \\
\hline Protein (\%) & 23 & 22.00 & 0.94 \\
\hline Calcium (\%) & 0.94 & 0.94 & 0.48 \\
\hline Available P(\%) & 0.48 & 0.48 & 1.00 \\
\hline Lysine (\%) & 1.25 & 1.14 & 0.45 \\
\hline Methionine (\%) & 0.58 & 0.53 & 158.97 \\
\hline ME:CP & 130.43 & 140.90 & 1.95 \\
\hline Ca:P & 1.95 & 1.95 & \\
\hline Vitat & & & \\
\hline
\end{tabular}

Vitamin-mineral premix contained the following per kg of premix: all-trans retinol, $548.4 \mathrm{mg}$; cholecalciferol, $22.025 \mathrm{mg}$; DL-tocopherol, $3397 \mathrm{mg}$; menadione sodium bisulphite, $1460 \mathrm{mg}$; vitamin $\mathrm{B}_{12}$, $4.4 \mathrm{mg}$; biotin, $18.4 \mathrm{mg}$; choline chloride, $257000 \mathrm{mg}$; folic acid, $330 \mathrm{mg}$; niacin, $14690 \mathrm{mg}$; D-pantothenic acid, $3670 \mathrm{mg}$; pyridoxine hydrochloride, $1100 \mathrm{mg}$; riboflavin, $1830 \mathrm{mg}$; thiamine mononitrate, $735 \mathrm{mg}$; $\mathrm{Cu}$ (as copper sulphate), $1480 \mathrm{mg}$; I (as calcium iodate), $370 \mathrm{mg}$; Fe (as ferrous sulphate), $14690 \mathrm{mg}$; Mn (as manganese oxide),22 $020 \mathrm{mg}$. 
Table.2 Effect of two sources and levels of sodium selenite and selenium enriched yeast supplementation on various carcass cuts of broiler chicken (as Percentage of Live Weight) at 0-

$35 \mathrm{~d}(\mathrm{gm} / \mathrm{bird})$

\begin{tabular}{|c|c|c|c|c|c|c|c|c|c|c|}
\hline \multirow[t]{3}{*}{ Particular } & \multicolumn{9}{|c|}{ Individual effect } & \multirow{3}{*}{$\begin{array}{r}\text { Signific } \\
\text { ant }\end{array}$} \\
\hline & \multicolumn{4}{|c|}{ Group I (SS) } & Sig & \multicolumn{4}{|c|}{ Group II (SY) } & \\
\hline & \multirow{2}{*}{\multicolumn{2}{|c|}{$\begin{array}{l}\mathbf{0 . 1 5} \mathbf{~ p p m} \\
69.74 \pm 0.58\end{array}$}} & \multicolumn{2}{|c|}{0.5 ppm } & & \multicolumn{2}{|c|}{0.15 ppm } & \multicolumn{2}{|c|}{0.5 ppm } & \\
\hline $\begin{array}{l}\text { Dressed wt. } \\
(\%)\end{array}$ & & & $58.05 \pm$ & 1.27 & NS & $70.65 \pm 0$ & $52^{\mathrm{b}}$ & $73.23 \pm$ & $0.59^{\mathrm{a}}$ & ** \\
\hline Liver wt. (\%) & \multicolumn{2}{|c|}{$1.77 \pm 0.10$} & \multicolumn{2}{|c|}{$1.76 \pm 0.28$} & NS & \multicolumn{2}{|c|}{$1.86 \pm 0.13$} & \multicolumn{2}{|c|}{$2.09 \pm 0.19$} & NS \\
\hline Heart wt. (\%) & \multicolumn{2}{|c|}{$0.45 \pm 0.02$} & \multicolumn{2}{|c|}{$0.44 \pm 0.00$} & NS & \multicolumn{2}{|c|}{$0.46 \pm 0.04$} & \multicolumn{2}{|c|}{$0.48 \pm 0.01$} & NS \\
\hline $\begin{array}{l}\text { Intestine wt. } \\
(\%)\end{array}$ & \multicolumn{2}{|c|}{$3.33 \pm 0.07$} & \multicolumn{2}{|c|}{$3.88 \pm 0.23$} & NS & \multicolumn{2}{|c|}{$3.44 \pm 0.24$} & \multicolumn{2}{|c|}{$3.07 \pm 0.32$} & NS \\
\hline Breast wt. (\%) & \multicolumn{2}{|c|}{$12.62 \pm 0.91$} & \multicolumn{2}{|c|}{$11.48 \pm 0.40$} & NS & \multicolumn{2}{|c|}{$13.50 \pm 0.30$} & \multicolumn{2}{|c|}{$13.50 \pm 0.30$} & NS \\
\hline Thigh wt. (\%) & \multicolumn{2}{|c|}{$19.89 \pm 1.00$} & \multicolumn{2}{|c|}{$19.74 \pm 0.19$} & NS & \multicolumn{2}{|c|}{$20.41 \pm 0.62$} & \multicolumn{2}{|c|}{$19.89 \pm 1.00$} & NS \\
\hline Wing wt. (\%) & \multicolumn{2}{|c|}{$18.86 \pm 1.09$} & \multicolumn{2}{|c|}{$18.60 \pm 1.95$} & NS & \multicolumn{2}{|c|}{$19.62 \pm 0.89$} & 18.94 & \pm 0.52 & NS \\
\hline $\begin{array}{l}\text { Back \& Neck } \\
\text { wt. (\%) }\end{array}$ & $11.81 \pm$ & & $11.59 \pm$ & 0.35 & NS & $11.95 \pm($ & & 14.11 & \pm 1.01 & NS \\
\hline Giblet wt. (\%) & $4.39 \pm 0$ & & $4.38 \pm 0$ & 0.17 & NS & $4.27 \pm 0$ & & $4.73 \pm 0$ & .12 & NS \\
\hline & & & & & erall & ffect & & & & \\
\hline Particular & Leve & effer & & Sig & & Source & effect & & Sig & Interac \\
\hline & 0.15 ppm & & ppm & & & SS & & SY & & $(\mathbf{L} \times \mathbf{S})$ \\
\hline $\begin{array}{l}\text { Dressed wt. } \\
(\%)\end{array}$ & $69.19 \pm 0.42$ & 70. & $4 \pm 1.31$ & NS & & $89 \pm 0.73$ & 70.9 & \pm 1.08 & NS & $*$ \\
\hline $\begin{array}{l}\text { Liver wt. } \\
(\%)\end{array}$ & $1.80 \pm 0.07$ & & \pm 0.17 & NS & & $80 \pm 0.14$ & & $3 \pm 0.12$ & NS & NS \\
\hline $\begin{array}{l}\text { Heart wt. } \\
(\%)\end{array}$ & $0.47 \pm 0.02$ & 0.4 & \pm 0.00 & NS & & $46 \pm 0.01$ & & \pm 0.02 & NS & NS \\
\hline $\begin{array}{l}\text { Intestine } \\
\text { wt. }(\%)\end{array}$ & $3.38 \pm 0.11$ & & \pm 0.25 & NS & & $26 \pm 0.20$ & & \pm 0.16 & NS & NS \\
\hline $\begin{array}{l}\text { Breast wt. } \\
(\%)\end{array}$ & $13.36 \pm 0.69$ & 12.4 & $9 \pm 0.50$ & NS & 12.0 & $\pm 0.51^{b}$ & 13.8 & $0 \pm 0.49^{\mathrm{a}}$ & $*$ & NS \\
\hline $\begin{array}{l}\text { Thigh wt. } \\
(\%)\end{array}$ & $20.09 \pm 0.27$ & 20.1 & $5 \pm 0.54$ & NS & & $42 \pm 0.34$ & 19.8 & $2 \pm 0.45$ & NS & NS \\
\hline $\begin{array}{l}\text { Wing wt. } \\
\text { (\%) }\end{array}$ & $19.24 \pm 0.65$ & 18.7 & $7 \pm 0.90$ & NS & & $28 \pm 0.48$ & 18. & $3 \pm 1.00$ & NS & NS \\
\hline $\begin{array}{l}\text { Back \& Neck } \\
\text { wt. (\%) }\end{array}$ & $11.88 \pm 0.22$ & 11.8 & $7 \pm 0.28$ & NS & & $99 \pm 0.26$ & 11.7 & $7 \pm 0.22$ & NS & NS \\
\hline $\begin{array}{l}\text { Giblet wt. } \\
(\%)\end{array}$ & $4.33 \pm 0.11$ & 4.5 & \pm 0.15 & NS & & \pm 0.12 & & $3 \pm 0.14$ & NS & NS \\
\hline
\end{tabular}

Superscripts are read row wise for comparison of means. Means \pm SE, in the same row with different superscripts a and $\mathrm{b}$ are significantly different $*(\mathrm{P}<0.05), * *(\mathrm{P}<0.01)$, Sig. $=$ Significant, NS $=$ Non-Significant., SS: Sodium selenite, SY: Selenium enriched yeast, L: level, S: Source 
Table.3 Effect of two sources and levels of sodium selenite and selenium enriched yeast supplementation on meat quality in broiler chicken (35 d) of age

\begin{tabular}{|c|c|c|c|c|c|c|c|}
\hline \multirow[t]{3}{*}{ Particular } & \multicolumn{6}{|c|}{ Individual effect } & \multirow{3}{*}{$\underset{t}{\text { Significan }}$} \\
\hline & \multicolumn{2}{|c|}{ Group ISS } & & \multicolumn{3}{|c|}{ Group IISY } & \\
\hline & $\begin{array}{c}\text { T1 (0.15 } \\
\text { ppm) }\end{array}$ & $\begin{array}{c}\text { T2 (0.5 } \\
\text { ppm) }\end{array}$ & Sig. & $\begin{array}{c}\text { T3 (0.15 } \\
\text { ppm) }\end{array}$ & \multicolumn{2}{|c|}{ T4 (0.5 ppm) } & \\
\hline WHC \% & $68.04 \pm 0.79$ & $70.75 \pm 1.37$ & NS & $73.08 \pm 1.11$ & \multicolumn{2}{|c|}{$74.18 \pm 0.57$} & NS \\
\hline ERV (ml) & $24.26 \pm 0.58$ & $22.93 \pm 1.19$ & NS & $24.26 \pm 0.48$ & \multicolumn{2}{|c|}{$27.04 \pm 0.88^{\mathrm{a}}$} & $*$ \\
\hline TBA value & $0.27 \pm 0.00$ & $0.30 \pm 0.00$ & NS & $0.24 \pm 0.01$ & \multicolumn{2}{|c|}{$0.22 \pm 0.02$} & NS \\
\hline \multicolumn{8}{|c|}{ Overall effect } \\
\hline \multirow[t]{2}{*}{ Particular } & \multicolumn{2}{|c|}{ Level effect } & Sig. & \multicolumn{2}{|c|}{ Source effect } & \multirow[t]{2}{*}{ Sig. } & \multirow{2}{*}{$\begin{array}{c}\text { Interactio } \\
\text { n(LxS) }\end{array}$} \\
\hline & 0.15 PPM & 0.5 PPM & & SS & SY & & \\
\hline WHC \% & $70.56 \pm 1.28$ & $72.46 \pm 1.01$ & NS & $\begin{array}{c}59.39 \pm 0.93 \\
b\end{array}$ & $\begin{array}{c}73.63 \pm 0.6 \\
1^{\mathrm{a}}\end{array}$ & $* *$ & NS \\
\hline ERV (ml) & $24.26 \pm 0.33$ & $24.99 \pm 1.13$ & NS & $23.60 \pm 0.66$ & $\begin{array}{c}25.65 \pm 0.7 \\
6\end{array}$ & NS & $*$ \\
\hline TBA value & $0.26 \pm 0.01$ & $0.26 \pm 0.02$ & NS & $0.28 \pm 0.01^{\mathrm{a}}$ & $0.23 \pm 0.00^{b}$ & $* *$ & NS \\
\hline
\end{tabular}

Superscripts are read row wise for comparison of means. Means \pm SE, in the same row with different superscripts a and $\mathrm{b}$ are significantly different $*(\mathrm{P}<0.05), * *(\mathrm{P}<0.01)$, Sig.= Significant, NS= Non-Significant.,SS: Sodium selenite, SY: Selenium enriched yeast, L: level, S: Source

The WHC percent and TBA value due to level effect were non-significant, however source effect showed highly significant $(\mathrm{p}<0.01)$ difference for WHC percent and TBA value. The WHC \% supplemented with selenium enriched yeast was significantly $(\mathrm{p}<0.01)$ higher than sodium selenite supplementation, however, TBA value supplemented with sodium selenite was significantly higher than selenium enriched supplementation. The interaction effect in WHC percent and TBA value were nonsignificant.

Significantly higher ERV $\mathrm{ml}$ was recorded in $0.5 \mathrm{ppm}$ supplementation of selenium enriched yeast, however, level and sources effect did not affect ERV (ml) in poultry, while two sources of selenium affected the water holding capacity and TBA value in selenium enriched yeast supplemented group. The finding was in corroborated with result of Wang et al., (2009); Boiago et al., (2014) and
Rajashree et al., (2014), who reported improved meat quality through decreased lipid peroxidation.

In conclusion overall selenium enriched yeast source improved carcass characteristics and meat quality of broiler chicken. Significantly higher WHC \% and lower TBA value were recorded with $0.5 \mathrm{ppm}$ of selenium enriched yeast.

\section{Acknowledgements}

I acknowledge the support provided by Department of Animal Nutrition, College of Veterinary Science and A.H., Anjora, Durg for undertaking this research as part of my M.V.Sc. degree requirement.

\section{Ethical standards}

The research work has been approved by the ethical committee before undertaking work. 


\section{References}

Alian, H. A., Samy, H. M., Ibrahim, M. T., \& Mahmoud, M. M., 2020. Nanoselenium effect on growth performance, carcass traits, antioxidant activity, and immune status of broilers. Environmental Science and Pollution Research, 1-10.

Bakhshalinejad, R., Akbari, M. K. R. and Zoidis, E., 2018. Effects of different dietary sources and levels of selenium supplements on growth performance, antioxidant status and immune parameters in Ross 308 broiler chickens. British poultry science, 59(1):81-91.

Baltic, M.Z., Starcevic, M.D., Basic, M., Zenunovic, A., Ivanovic, J., Markovic, R., Janjic, J. and Mahmutovic, H., 2015. Effects of selenium yeast level in diet on carcass and meat quality, tissue selenium distribution and glutathione peroxidase activity in ducks. Animal Feed Science and Technology, 210:225-233.

Boiago, M.M., Borba, H., Leonel, F.R., Giampietro-Ganeco, A., Ferrari, F.B., Stefani, L.M. and Souza, P.A.D., 2014. Sources and levels of selenium on breast meat quality of broilers. Ciência Rural, 44(9): 1692-1698.

Boostani, A., Sadeghi, A.A., Mousavi, S.N., Chamani, M. and Kashan, N., 2015. Effects of organic, inorganic, and nano-Se on growth performance, antioxidant capacity, cellular and humoral immune responses in broiler chickens exposed to oxidative stress. Livestock science, 178: 330-336.

Choct, M., Naylor, A.J. and Reinke, N., 2004. Selenium supplementation affects broiler growth performance, meat yield and feather coverage. British Poultry Science, 45(5): 677-683.

Da Silva, I.C.M., Ribeiro, A.M.L., Canal,
C.W., Trevizan, L., Macagnan, M., Gonçalves, T.A., Hlavac, N.R.C., De Almeida, L.L. and Pereira, R.A., 2010. The impact of organic and inorganic selenium on the immune system of growing broilers submitted to immune stimulation and heat stress. Brazilian Journal of Poultry Science, 12(4):247-254.

Deniz, G., Gezen, S.S. and Turkmen, I.I., 2005. Effects of two supplemental dietary selenium sources (mineral and organic) on broiler performance and drip-loss. Revue de médecinevétérinaire, 156(8/9):423.

Duncan, D.B., (1955). Multiple range and multiple F tests. Biometrics, 11(1), 142.

European Commission, 2014. European Union Register of Feed Additives.

FDA, 2000. FDA approves food additive petition for selenium yeast. FDA Veterinarian Newsletter (July/August). U.S. Food and Drug Administration, Washington, D.C.

Fernandez-Lopez, J., Zhi, N., AlesonCarbonell, L., Pérez-Alvarez, J.A. and Kuri, V., 2005. Antioxidant and antibacterial activities of natural extracts: application in beef meatballs. Meat science, 69(3): 371-380.

Fridovich, I., 1978. The biology of oxygen radicals. Science, 201(4359): 875880.

Gao, X., Xing, H., Li, S., Li, J., Ying, T. and $\mathrm{Xu}, \mathrm{S} .$, 2012. Selenium regulates gene expression of selenoprotein $\mathrm{W}$ in chicken gastrointestinal tract. Biological Trace Element Research, 145(2):181-188.

Grashorn, M., 2007. Functionality of poultry meat. Journal of Applied Poultry Research, 16: 99-106.

Harris, P.V. and Shorthose, W.R., 1988. Water holding capacity measurements. In: developments in 
meat science-4. (R. Lawrie, Ed.). Elsevier Applied Science, New York.

Heindl, J., Ledvinka, Z., Englmaierova, M., Zita, L. and Tumova, E., 2010. The effect of dietary selenium sources and levels on performance, selenium content in muscle and glutathione peroxidase activity in broiler chickens. Czech Journal of Animal Science, 55(12):572-578.

ICAR - Indian Council of Agricultural Research. Nutrient requirements of commercial white and coloured broiler chickens. 2013. Krishi Bhavan, Dr. Rajendra Prasad Road, New Delhi-110001. Immunology and Immunopathology. 30:111-120.

Livestock Statistics. (2017-18) Department of Animal Husbandry and Dairying, Government of India.www.dahd.nic.in

Mahmoud, K. Z., \&Edens, F. W., 2003. Influence of selenium sources on agerelated and mild heat stress-related changes of blood and liver glutathione redox cycle in broiler chickens (Gallus domesticus). Comparative Biochemistry and Physiology Part B: Biochemistry and Molecular Biology, 136(4), 921-934.

Markovic, R., Ciric, J., Drljacic, A., Sefer, D., Jovanovic, I., Jovanovic, D., Milanovic, S., Trbovic, D., Radulovic, S., Baltic, M.Z. and Starcevic, M., 2018. The effects of dietary Seleniumyeast level on glutathione peroxidase activity, tissue Selenium content, growth performance, and carcass and meat quality of broilers. Poultry Science, 97(8): 2861-2870.

Mikulski, D., Jankowski, J., Zduńczyk, Z., Wroblewska, M., Sartowska, K. and Majewska, T., 2009. The effect of selenium source on performance, carcass traits, oxidative status of the organism, and meat quality of turkeys. Journal of Animal and Feed Sciences,
18(3): 518-530.

Mohamed, D. A., Sazili, A. Q., TeckChwen, L., and Samsudin, A. A., 2020. Effect of Microbiota-Selenoprotein on Meat Selenium Content and Meat Quality of Broiler Chickens. Animals, 10(6), 981.

Mohanty, P. P., Panda, N, Swain, R. K., Behura, N. C, Ray, P., Sethi, A. K., and Panigrahi, S., 2018. A Comparison between Organic and Inorganic Selenium: 1. Effect on Body Weight, Laying Performance, Hatchability in Broiler Breeder. International Journal Current Microbial Application. Science. 7(5): 173-179.

Morrissey, P.A., Buckley, D.J., Sheehy, P.J.A. and Monahan, F.J., 1994. Vitamin $\mathrm{E}$ and meat quality. Proceedings of the Nutrition Society, 53(2): 289-295.

National Research Council, 1994. Nutrient Requirements of Poultry: 1994. National Academies Press.

Naylor, A.J. and Choct, M., 2000. Effects of selenium source and level on performance, mortality and meat quality in male broilers. In Proceedings of the Australian Poultry Science Symposium 2000. Poultry Research Foundation, University of Sydney.

Niu, Z.Y., Liu, F.Z., Yan, Q.L. and Li, W.C., 2009. Effects of different levels of vitamin $\mathrm{E}$ on growth performance and immune responses of broilers under heat stress. Poultry Science, 88(10): 2101-2107.

Nunes, V.A., Gozzo, A.J., Cruz-Silva, I., Juliano, M.A., Viel, T.A., Godinho, R.O., Meirelles, F.V., Sampaio, M.U., Sampaio, C.A. and Araujo, M.S., 2005. Vitamin E prevents cell death induced by mild oxidative stress in chicken skeletal muscle cells. Comparative Biochemistry and 
Physiology Part C: Toxicology \& Pharmacology, 141(3): 225-240.

Okunlola, D.O., Akande, T.O. and Nuga, H.A., 2015. Haematological and serum characteristics of broiler birds fed diets supplemented with varying levels of selenium powder journal of biology. Agriculture and Healthcare, 5(1):107-10.

Oliveira, T.F.B., Rivera, D.F.R., Mesquita, F.R., Braga, H., Ramos, E.M. and Bertechini, A.G., 2014. Effect of different sources and levels of selenium on performance, meat quality, and tissue characteristics of broilers. Journal of Applied Poultry Research, 23(1): 15-22.

Payne, R.L. and Southern, L.L., 2005. Comparison of inorganic and organic selenium sources for broilers. Poultry Science, 84(6):898-902.

Pearson, D. (1968). The correlation of the extract-release volume of stored beef with other spoilage values. International Journal of Food Science \& Technology, 3(3), 207-214.

Peric, L., Milosevic, N., Zikic, D., Kanacki, Z., Dzinic, N., Nollet, L. and Spring, P., 2009. Effect of selenium sources on performance and meat characteristics of broiler chickens. Journal of Applied Poultry Research, 18(3): 403-409.

Prasad, M.V., 2019. Comparative Efficacy of Selenized yeast and Inorganic Selenium on Performance, Nutrient Retention and Antioxidant Status in Commercial Broilers (Doctoral dissertation, pvnrtvu). krishikosh.egranth.ac.in.

Rajashree, K., Muthukumar, T. and Karthikeyan, N., 2014. Influence of Inorganic and Organic Selenium Sources on Broiler Performance and Meat Quality. Iranian Journal of Applied Animal Science, 4(1):110-
112.

Rao, S.V.R., Prakash, B., Raju, M.V.L.N., Panda, A.K., Poonam, S. and Murthy, O.K., 2013. Effect of supplementing organic selenium on performance, carcass traits, oxidative parameters and immune responses in commercial broiler chickens. Asian-Australasian journal of animal sciences, 26(2): 247.

Rotruck, J. T., Pope, A. L., Ganther, H. E., Swanson, A. B., Hafeman, D. G., \& Hoekstra, W. ,1973. Selenium: biochemical role as a component of glutathione peroxidase. Science, 179(4073), 588-590

Sevcikova, S., Skrivan, M., Dlouha, G., and Koucky, M., 2006. The effect of selenium source on the performance and meat quality of broiler chickens. Czech Journal of Animal Science, 51(10): 449-457.

Snedecor, G. W. and Cochran, W. G., 1994. Statistical Methods. (8th ed.) Affiliated East- West Press, Pvt. Ltd, New Delhi, India.

Strange, E.D., Benedict, R.C., Smith, J.L. and Swift, C.E., 1977. Evaluation of rapid tests for monitoring alterations in meat quality during storage: I. Intact meat. Journal of Food Protection, 40(12): 843-847.

Suchy, P., Straková, E. and Herzig, I., 2014. Selenium in poultry nutrition: a review. Czech Journal of Animal Science, 59(11): 495-503.

Surai, P.F. and Fisinin, V.I., 2014. Selenium in poultry breeder nutrition: An update. Animal Feed Science and Technology, 191: 1-15.

Tappel, A. and Tappel, A., 2004. Oxidant free radical initiated chain polymerization of protein and other biomolecules and its relationship to diseases. Medical hypotheses, 63(1): 98-99.

Thompson, J.N. and Scott, M.L., 1969. Role 
of selenium in the nutrition of the chick. The Journal of Nutrition, 97(3): 335-342.

Wang, Y., Zhan, X., Zhang, X., Wu, R. and Yuan, D., 2011. Comparison of different forms of dietary selenium supplementation on growth performance, meat quality, selenium deposition, and antioxidant property in broilers. Biological Trace Element Research, 143(1): 261-273.

Wang, Z.G., Pan, X.J., Peng, Z.Q., Zhao, R.Q. and Zhou, G.H., 2009. Methionine and selenium yeast supplementation of the maternal diets affects color, water-holding capacity, and oxidative stability of their male offspring meat at the early stage.
Poultry Science, 88(5): 1096-1101.

Wiseman, H. and Halliwell, B., 1996. Damage to DNA by reactive oxygen and nitrogen species: role in inflammatory disease and progression to cancer. Biochemical Journal, 313(1): 17-19.

Yang, Y.R., Meng, F.C., Wang, P., Jiang, Y.B., Yin, Q.Q., Chang, J., Zuo, R.Y., Zheng, Q.H. and Liu, J.X., 2012. Effect of organic and inorganic selenium supplementation on growth performance, meat quality and antioxidant property of broilers. African Journal of Biotechnology, 11(12): 3031-3036.

\section{How to cite this article:}

Roshan Kumar Sahu, M. K. Gendley, Meenu Dubey, G. K. Dutta, Ramchandra Ramteke, Raina Doneria, SonaliPrusty and Kiran Kumari. 2020. Sources and Levels Effect of Sodium Selenite and Selenium Enriched Yeaston Carcass Characteristics in Broiler Chicken. Int.J.Curr.Microbiol.App.Sci. 9(10): 1785-1795. doi: https://doi.org/10.20546/ijcmas.2020.910.217 